\title{
GENDER AND AGE FACTORS IN SUBJECTIVE WELLBEING AND QUALITY OF LIFE AMONG COLLEGE STUDENTS
}

\author{
Ayu Kurnia ${ }^{1}$, Dian Veronika Sakti Kaloeti ${ }^{2}$, Kwartarini Wahyu Yuniarti ${ }^{3}$, Ahmad \\ Gimmy Prathama Siswandi ${ }^{4}$, Josetta Maria Remila ${ }^{5}$
}

\author{
${ }^{1}$ Master of Psychology, Universitas Diponegoro, Indonesia \\ Jl. Prof. Soedarto, SH, Kampus Undip Tembalang, Semarang, Indonesia 50275 \\ ${ }^{2}$ Center of Family Empowerment, Faculty of Psychology, Universitas Diponegoro, Indonesia \\ Jl. Prof. Soedarto, SH, Kampus Undip Tembalang, Semarang, Indonesia 50275 \\ ${ }^{3}$ Faculty of Psychology, Gadjah Mada University, Indonesia \\ Jl. Sosio Humaniora Bulaksumur, Karang Malang, Caturtunggal, Depok, Sleman, Daerah Istimewa Yogyakarta \\ 55281 \\ ${ }^{4}$ Faculty of Psychology, Padjajaran University, Indonesia \\ Hegarmanah, Jatinangor, Kabupaten Sumedang, Jawa Barat \\ ${ }^{5}$ Faculty of Psychology, South Sumatra University, Indonesia \\ Indralaya Indah, Kec. Indralaya, Kabupaten Ogan Ilir, Sumatera Selatan 30862
}

dvs.kaloeti@live.undip.ac.id

\begin{abstract}
Quality of life (QOL) and subjective well-being (SWB) among college students have been deemed as important issues in studies. The present study aims to explore any influential elements of gender and age to their QOL and SWB, and to know if the QOL is influential to the SWB. Participants amounted to 651 respondents totally from three Indonesian universities (Diponegoro University, Padjajaran University, North Sumatra University) were involved in a purposive sampling using two instruments, i.e., the Personal Wellbeing Index-Adult (PWI-A) to measure SWO and The World Health Organization Quality of Life-BREF (WHOQOL-BREF) to measure QOL. Ordinal Logistic Regression (OLR) test was used in the analysis. The results showed that age and gender had a significant effect on SWB (respectively $.11 \& .040$, with $p<.05$ ) but had no effect on QOL of students (respectively $.510 \& .751$, with $p<.05$ ). In addition, QOL was shown to affect SWB $(p<.05)$. As a result, counselors and stakeholders on campus are encouraged to consider age and sex factors in their attempts of increasing college students' SWB. However, further research is still suggestible to explore more complex factors in college students' QOL, which can include social, individual, and other demographic factors.
\end{abstract}

Keywords: gender, Subjective Wellbeing (SWB), Quality of Life (QOL), college students

\section{INTRODUCTION}

The terms quality of life (QOL) and subjective well-being (SWB) tend to be used overlappingly each other because of their conceptual intersection: Both deal with subjective conditions within individuals (John \& Wright, 2008). In this consideration, studies over the last few years have been trying to discuss QOL and SWB simultaneously to explain the differences in terminology built (John \& Wright, 2008), causality relationships (Medvedev \& Landhuis, 2018; Skevton \& Böhnke, 2018) and composing factors (Camfield \& Skevington, 2008). Quality of life focuses on individuals' perceived positions in lives, including satisfaction and dissatisfaction as well as happiness and unhappiness, while SWB emphasizes on individuals' assessments or evaluations of the overall qualities of lives and the extent to which they are satisfied with their lives (John \& Wright, 2008).

QOL and SWB have found their own importance in the studies of college students (Malkoç, 2011). The students frequently perceive various problems from lack of nutrition, limited accommodation, difficulty with new environments, anxiety about the future, to poor quality of education (Doygun \& Gulec, 2012). Perceived problems can further trigger mental complications in college students (Pedrelli, et al., 2014). Tu and Zhang (2014) added that students with low QOL are prone to loneliness, stress, and 
depression. In addition, there is a higher chance for them to grow fatigue and insomnia (Ribeiro et al., 2018). On the other hand, students with high QOL tend to perform well in physical activities and better in dealing with the perceived demands and problems of any kind (Joseph et al., 2014). Students with high QOL and SWB optimize their roles well in the learning environments, families, friendships, and communities (Coninck et al., 2019).

Therefore, scrutinizing over QOL's and SWB's compositional factors is necessary to decide what types and what levels of intervention to use when attempting to improve them in college students (John \& Wright, 2008). Camfield and Skevington (2008) stated that the dominant, influential factors for individuals' SWBs lie within internal realm, including self-control, selfesteem, optimism, and level of religiosity. In contrast, Utami (2015) placed more emphasis on that supportive social environment are proven to increase SWB. Coninck et al. (2019) also added that individuals' parentchild relationships also significantly promote SWB. The discussions on demographic factors have shown similarly mixed results. Bücker et al. (2018) revealed that gender and age have indirect relationships with SWB. Siedlecki et al. (2014) stated that SWBs are unaffected when individuals reach a certain age. In contrast to these studies, Coninck et al. (2019) and Cherepanov et al. (2010) insisted that gender and age affect SWB and QOL in individuals.

College students experience transitions between adolescence and adulthood, where new biological, social, and psychological factors simultaneously emerge, interact, and render them vulnerable to negative impacts on their long-term health and survivals (Aucott et al., 2014). Interventions adjusted on the basis of age and gender are considered more sensitive and more successful to bring positive effects related to achieving program objectives (Abdullahi et al., 2019). Therefore, exploring the compositional roles of age and sex in SWB and QOL in college students should be the basis of any appropriate interventions recommended for their conditions. Our study aims to fulfil this exploration and to know the degree of which QOL affects their SWB.

\section{METHOD}

\section{Research participants}

Participants amounted to 651 respondents totally from three Indonesian Universities (Diponegoro University, Padjajaran University, North Sumatra University) were involved in purposive sampling. The inclusive criteria include: (1) registered as a student of either one of the predetermined universities, (2) currently having active student status, (3) willing to participate as proven by informed consent.

\section{Research tools}

This study adopts the Personal Wellbeing Index-Adult (PWI-A) and The World Health Organization Quality of Life-BREF (WHOQOL-BREF), which are presented to the respondents in the Indonesian-translated version. First compiled by Robbert A. Cummins in 1994 and developed further to the latest edition in 2013 (Cummins \& Lau, 2013), PWI-A is used to measure subjective well-being (Tomyn et al., 2013). It was adapted into Indonesian by Masyita Haerianti in 2017 using the 1986's Brislin translation model with 4 sequential procedures: forward translation, expert review, back translation, and comparison between the source language version and the back translation version (Haerianti et al., 2017). PWI-A consists of 2 aspects: the subjective well-being aspect consisting of 7 items (e.g.: "How satisfied are you with your standard of living?"); and spirituality/religious aspect consisting of one item (i.e., "How satisfied are you with your spirituality or religion?"). A continuum scale from 1 (very unsatisfactory) to 10 (very satisfactory) is adopted. While the average scores in items 1 to 7 indicate the condition of individual subjective well-being, item number 8 is a separate section in which individuals' 
conditions of spirituality or religiosity can be observed. This means that the assessments of the two aspects can be used separately. In this study, the PWI-A reliability coefficient is calculated to be .877 .

Comparatively, the WHOQOL-BREF is used to measure an individual's quality of life (Mental Health Division, 1996). The 26 items in WHOQOL-BREF are grouped into 4 domains, i.e., the physical health (e.g., To what extent do you feel that physical pain prevents you from doing what you need to do?), psychological (e.g., How much do you enjoy life?), social relationships (e.g. How satisfied are you with your sex life?), and environment (e.g. How healthy is your physical environment?). The assessment applies a Likert scale of 1 (not at all) to 5 (extremely). The reliability coefficient is calculated to be 0.94 . The total value assessed with WHOQOL-BREF describes an individual's quality of life.

\section{Data collection}

The research uses data from an umbrella research registered in the 2019's Citation Improvement Program funded by Diponegoro University through its World Class University program. The later research is entitled "Hypnotic Guided Imagery for Emotional Correction in Psychotherapy-Mapping the
Effectiveness and Psychological Dynamic of Psychophysiological Measurement". The data were collected by visiting students of the three, targeted universities directly after lectures and distributing them the questionnaires. The participation in this study is voluntary, as marked by their signing the provided informed consents. After filling this out, participants were directed to do the questionnaires.

\section{Data analysis}

The data is analyzed using IBM Statistical Package for Social Science (SPSS) version 22.0 for Windows. The analysis includes the descriptive statistics to see the description of research participants, and the Ordinal Logistic Regression (OLR) tests to find any influence of gender and age on the students' qualities of lives and subjective well-beings, as well as any influence of the qualities of lives on the subjective well-beings.

\section{RESULT AND DISCUSSION}

\section{Participant demographics}

Most of the participants in this study were women $(79.1 \%)$. Most of them are also within the age range of 20-24 years (61.59\%). In addition, the highest number of participants came from the University of North Sumatra (46.23\%). More details of the demographics can be seen in table 1 .

Table 1.

Demographics Data of Research

Participants

\begin{tabular}{lcc}
\hline \multicolumn{1}{c}{ Category } & \multicolumn{2}{c}{ Total } \\
\cline { 2 - 3 } Gender & $n$ & $\%$ \\
\hline Man & & \\
\hline Woman & 5136 & 20.89 \\
\hline Age & & \\
\hline $15-19$ & 115 & 17.66 \\
\hline $20-24$ & 401 & 61.59 \\
\hline $25-28$ & 95 & 14.59 \\
\hline$>29$ & 40 & 6.14 \\
\hline University & & \\
\hline Universitas Diponegoro & 150 & 23.04 \\
\hline$\quad$ Padjajaran University & 200 & 30.72 \\
\hline South Sumatra University & 301 & 46.23 \\
\hline
\end{tabular}


Table 2.

Factors Predicting SWB and Quality of Life According to Ordinal Logistic Regression Analysis

\begin{tabular}{lcc}
\hline \multicolumn{1}{c}{ Variable } & $\begin{array}{c}\text { Model 1 } \\
\text { Sey independent variables }\end{array}$ & $\begin{array}{c}\text { Model 2 } \\
\text { Quality of Life (QoL) }\end{array}$ \\
\hline Age & $.02^{*}$ & $.04^{*}$ \\
{$[$ Gender $=1.00]$} & $.21^{*}$ & $-.23^{*}$ \\
{$[$ Gender $=0.00]$} &. &. \\
Quality of Life (QoL) & $.91^{* * *}$ &. \\
\hline Model fit statistics & & 647 \\
\hline$d f$ & 647 & 6.84 \\
AIC & 2.95 & .410 \\
$R^{2}$ & .426 & $149.733^{* * *}$ \\
$F$-Statistic & $160.004^{* * *}$ & 1.811 \\
Durbin-Watson Stat & 1.915 & \\
\hline
\end{tabular}

Notes. $N=651$. Gender: $1.00=$ male, $0.00=$ female.

${ }^{*} p<.05 .{ }^{* * *} p<.001$.

Gender and age influences on subjective wellbeing (SWB)

Ordinal Logistic Regression (OLR) calculation of the probability of the gender variable showed a value of .04 (with $p<.05$ ), which means that gender differences affect SWB in college students (Table 2). Meanwhile, the probability value for the age variable is .11 (with $p>.05$ ), thus indicating that age differences significantly affect the SWB. In other words, the higher the age is, the higher the score of the individual SWB will be. Studies have varied views regarding the results in the present study. For example, Siedlecki et al. (2014) stated that a person's SWB is not determined by his/her age. However, Bücker et al. (2018) stated that age and gender do have some indirect relationship with SWB. Along with it, Coninck et al. (2019) stated that a person's gender and age have actual effects on the individual's SWB.

In college students, the age influence is apparent perhaps because they are young adult individuals who tend to actively perceive well-beings in social relationships, as shown through numerous organizational activities, habits to hangout, and relationships building (Abdullahi et al., 2019). Moreover, educational institutions should provide a wide space for students to become creative both in academic and non-academic fields via intracampus organizations that directly support social relations (Undip Chancellor Regulation Number 4, 2014). In contrast, late adults tend to perceive psychological well-being and life satisfaction through activities like spiritual values enhancements (Abdullahi et al., 2019).

It is interesting to note that the men's SWB coefficient value is .21 points greater than that of the women's (with an SWB value range of $0-7)$, suggesting that men have a higher level of subjective well-being. Batz and Tay (2018) stated in their literature review that gender difference determines individual's SWB. Although some literatures state that men have higher SWB scores than women, several other studies show the opposite results. This variation is determined by factors shaping the environments, including cultural, individual, and biological (Batz \& Tay, 2018). The study showed that, in countries with persistent patriarchal cultures, men's SWB scores tend to be higher than those of women's. Patriarchal culture exists steadily across Indonesian societies, for example from the fact that women become the majority in the domestic sector and men the main power holders in political leadership roles (Sakina \& Siti, 2017). In the students' lives at campus, 
most of the organizational leaders are still dominated by men, while the positions of secretaries are conveniently held by women. In addition, women tend to be more sensitive to social judgments and so they are more susceptible to worsen SWB conditions as compared to men (Vanhoutte \& Nazroo, 2014). On this basis, interventions need to be tailored to age and gender groups. Abdullahi et al. (2019) introduced a persuasive health intervention to upgrade SWB with adjustments based on age and gender groups.

In present study, the $\mathrm{R} 2$ value has been calculated to be .426 , which means that gender and age contributed $42.6 \%$ to individual SWB conditions, and the remaining $57.4 \%$ was explained by other variables outside this study. These other factors can comprise social and/or individuals' internal factors. Utami (2015) stated in her research that students who take part in extracurricular activities reveal higher SWBs than students who do not. This is in line with the finding that healthy friendship interactions serve to improve SWBs in individuals (Ratelle et al., 2013). In addition, Camfield and Skevington (2008) mentioned in their result on 194 students that a good maternal bond has higher potential to increase SWB than that of a paternal. Furthermore, they stated that income level cannot be a factor of SWB, because great ambitions for wealth tend lower SWBs. Meanwhile, selfcontrol, level of optimism, ability of food appreciation, level of religiosity and personality are internal elements determining individual's SWB (Coninck et al., 2019; Zhang \& Renshaw, 2020).

\section{Gender and age influences on quality of life (QOL)}

Regression tests using OLR reveal similar probability values for both gender and age variables, i.e., neither of them determines QOL (respectively .751, with $p>.05$, and .510 , with $p>.05$ ) (table 2). In line with it, Gondodiputro et al. (2018) stated that gender and age had no effect on QOL. Those are contrastive views to Cherepanov et al. (2010), who explained that gender factors significantly affect individuals' QOLs (with women scored lower than men) or to Baldwin et al. (2017), who suggested that gender significantly affects individual's QOL although he stated otherwise in case of age. In women, factors improving their QOLs include psychosocial and physical, while in men these are socioeconomic, physical, and psychosocial (Campos et al., 2014). In addition, it was reported that single-male students had higher levels of QOL than the married-female ones (Al-Naggar et al., 2013). It can be concluded that gender alone cannot affect the quality of life of individuals.

As for other factors, Nur et al. (2017) stated that living conditions, allowances, and body mass index are significant factors related to the students' QOL. In addition, individuals whose socioeconomic level higher are reported to score higher QOLs than those with moderate and low socioeconomic levels (Malkoç, 2011). Furthermore, Joseph et al. (2014) stated that self-confidence about an individual's physical condition can improve the quality of life of students. Even so, there is still an unsatiated need for further research on factors responsible for increasing the QOLs. Ideally, those research will include not only analysis of age and gender but also of other factors including environmental, cultural, socio-economical to the details such as allowances, body mass index, and selfconfidence of physical condition.

\section{QOL influences on SWB}

The influence of QOL on SWB is confirmed significant by probability value of .00 ( $p<$ $.05)$. In other words, SWB will ameliorate simultaneously with the rise of QOL. These findings gain supports from those of Malkoç (2011) and Kreitlow (2015) which stated that students' QOL affect their psychological health, social relationships and SWBs. Interestingly, Malkoç (2011) added that the QOLs responsible for the increase of SWBs 
are related to those of social relationships establishments, and not physical health.

The present study witnessed as much as $42.6 \%$ of QOL contribution to SWB formulation. Comparably, Medvedev and Landhuis (2018) revealed a percentage of $66 \%$ for QOL in this case, with psychological dimension being the most dominant influences. To sum up, QOLs interventions either by individuals, campus stakeholders, counselors, or families to boost SWBs will have to involve individuals' improved social qualities and psychological skills (including self-control, level of optimism, selfacceptance, and level of religiosity).

\section{CONCLUSION}

Contribution of gender and age to Quality of Life (QOL) and Subjective Wellbeing (SWB) in college students become the primary focus of this study. In addition, it attempts to reveal to what extent the QOL affects the SWB. Our result confirms that gender and age influences are significant on SWB but not significant on the students' QOLs. In addition, the quality of life of students is proven to affect SWB. These results can serve as the basis for counselors and stakeholders on campuses that they should consider age and gender factors in their attempts to increase college students' SWB. Nevertheless, further research is needed to explore the other social, individual and demographical factors in the complexity of QOL formulations of college students.

\section{ACKNOWLEDGEMENT}

This research was facilitated by a collaborative agreement between The Institute of Education Fund Management (LPDP) of Ministry of Finance of the Republic of Indonesia and the Directorate of Research at Gadjah Mada University via Productive Innovative Research Program (Rispro) with the contract number: PRJ36/LPDP/2019.

\section{REFERENCES}

Abdullahi, A. M., Orji, R., \& Kawu, A. A.
(2019). Gender, age and subjectivewellbeing: Towards personalized persuasive health interventions. Information, 10(10), $1-17$.

https://doi.org/10.3390/info10100301

Al-Naggar, R. A., Osman, M. T., \& Musa, R. (2013). Quality of life among university students in a single Malaysian Institute. Pensee Journal, 75(10), 167-179. https://doi.org/http://irep.iium.edu.my/id/ eprint $/ 30564$

Aucott, L., Poobalan, A., Mccallum, M., \& Smith, W. C. S. (2014). Mental well-being related to lifestyle and risky behaviours in 18-25 year old: Evidence from north-east scotland. International Journal of Public Health Research, 4(1), 431-440. https://abdn.pure.elsevier.com/en/publica tions/mental-well-being-related-tolifestyle-and-risky-behaviours-in-18

Baldwin, D. R., Towler, K., Oliver, M. D., \& Datta, S. (2017). An examination of college student wellness: A research and liberal arts perspective. Health Psychology Open, 4(2). https://doi.org/10.1177/20551029177195 63

Batz, C., \& Tay, L. (2018). Gender differences in subjective well-being. In E. Diener, S. Oishi, \& L. Tay (Eds.), Handbook of well-being. Salt Lake City, UT: DEF Publishers. https://doi.org/nobascholar.com

Bücker, S., Nuraydin, S., Simonsmeier, B. A., Schneider, M., \& Luhmann, M. (2018). Subjective well-being and academic achievement: A meta-analysis. Journal of Research in Personality, 74, 83-94. https://doi.org/10.1016/j.jrp.2018.02.007

Camfield, L., \& Skevington, S. M. (2008). On subjective well-being and quality of life. Journal of Health Psychology, 13(6), 764-775. https://doi.org/10.1177/13591053080938 60 
Campos, A. C. V., Ferreira, E. F. E., Vargas, A. M. D., \& Albala, C. (2014). Aging, Gender and Quality of Life (AGEQOL) study: Factors associated with good quality of life in older Brazilian community-dwelling adults. Health and Quality of Life Outcomes, 12(1), 1-11. https://doi.org/10.1186/s12955-0140166-4

Cherepanov, D., Palta, M., Fryback, D. G., \& Robert, S. A. (2010). Gender differences in health-related quality-of-life are partly explained by sociodemographic and socioeconomic variation between adult men and women in the US: Evidence from four US nationally representative data sets. Quality of Life Research, 19(8), 1115-1124.

https://doi.org/10.1007/s11136-0109673-x

Coninck, D. De, Matthijs, K., \& Luyten, P. (2019). Subjective well-being among first-year university students: A two-wave prospective study in Flanders, Belgium. Student Success, 10(1), 33-45. https://doi.org/10.5204/ssj.v10i1.642

Cummins, B., \& Lau, A. (2013). Personal Wellbeing Index [Database record]. Australian Centre on Quality of Life, Deakin University. http://www.acqol.com.au/uploads/pwia/pwi-a-english.pdf

Doygun, O., \& Gulec, S. (2012). The problems faced by university students and proposals for solution. Procedia - Social and Behavioral Sciences, 47, 1115-1123. https://doi.org/10.1016/j.sbspro.2012.06. 788

Gondodiputro, S., Rizki Hidayati, A., \& Rahmiati, L. (2018). Gender, age, marital status, and education as predictors to quality of life in elderly: WHOQOLBREF Indonesian version. International Journal of Integrated Health Sciences, 6(1), 36-41. https://doi.org/10.15850/ijihs.v6n1.1201
Haerianti, M., Warsini, S., \& Pangastutui, H. S. (2017). Faktor-faktor yang berhubungan dengan subjective wellbeing pasien penyakit ginjal kronik yang menjalani hemodialysis di ESUP Dr. Sardjito Yogyakarta [Master's thesis, University of Gadjah Mada]. UGM Repository.

http://etd.repository.ugm.ac.id/penelitian/ detail/128872

John, L., \& Wright, R. (2008). Quality of life and subjective well-being: Historical, conseptual, and methodological clarification. Social Work in Mental Health, 4(2), 47-65. https://doi.org/10.1300/J200v04n02

Joseph, R. P., Royse, K. E., Benitez, T. J., \& Pekmezi, D. W. (2014). Physical activity and quality of life among university students: Exploring self-efficacy, selfesteem, and affect as potential mediators. Quality of Life Research, 23(2), 661-669. https://doi.org/10.1007/s11136-013-

0492-8

Kreitlow, A. A. (2015). Religiosity , spirituality, and quality of life among selected university students. [Master's thesis, Minnesota State University]. Theses, Dissertations, and Other Capstone Projects.

https://citeseerx.ist.psu.edu/viewdoc/dow nload?doi=10.1.1.874.498\&rep=rep1\&ty $\mathrm{pe}=\mathrm{pdf}$

Malkoç, A. (2011). Quality of life and subjective well-being in undergraduate students. Procedia - Social and Behavioral Sciences, 15, 2843-2847. https://doi.org/10.1016/j.sbspro.2011.04. 200

Medvedev, O. N., \& Landhuis, C. E. (2018). Exploring constructs of well-being, happiness and quality of life. Peer Journal, 6(24903), 1-16. https://doi.org/10.7717/peerj.4903

Nur, N., Kıbık, A., Kılıç, E., \& Sümer, H. 
(2017). Health-related quality of life and associated factors among undergraduate university students. Oman Medical Journal, 32(4), 329-334. https://doi.org/10.5001/omj.2017.62

Mental Health Division. (1996). WHOQOLBREF: Introduction, administration, scoring and generic version of the assessment.

https://apps.who.int/iris/handle/10665/63 529

Pedrelli, P., Nyer, M., Yeung, A., Zulauf, C., \& Wilens, T. (2014). College students: mental health problems and treatment considerations. Academic Psychiatry, 39(5), 503-511. doi:10.1007/s40596-0140205-9

Ratelle, C. F., Simard, K., \& Guay, F. (2013). University students' subjective wellbeing: The role of autonomy support from parents, friends, and the romantic partner. Journal of Happiness Studies, 14(3), 893910. https://doi.org/10.1007/s10902-0129360-4

Ribeiro, Í. J. S., Pereira, R., Freire, I. V., de Oliveira, B. G., Casotti, C. A., \& Boery, E. N. (2018). Stress and quality of life among university students: a systematic literature review. Health Professions Education, 4(2), 70-77. https://doi.org/10.1016/j.hpe.2017.03.002

Sakina, A. I., \& Siti, D. H. (2017). Menyoroti budaya patriarki di Indonesia. Share: Social Work Journal, 7(1), 71-80. https://doi.org/10.24198/share.v7i1.1382 0

Siedlecki, K. L., Salthouse, T. A., Oishi, S., \& Jeswani, S. (2014). The relationship between social support and subjective well-being across age. Social Indicators Research, 117(2), 561-576. https://doi.org/10.1007/s11205-0130361-4
Skevington, S. M., \& Böhnke, J. R. (2018). How is subjective well-being related to quality of life? Do we need two concepts and both measures? Social Science and Medicine, 206, 22-30. https://doi.org/10.1016/j.socscimed.2018. 04.005

Tomyn, A. J., Fuller Tyszkiewicz, M. D., \& Cummins, R. A. (2013). The personal wellbeing index: Psychometric equivalence for adults and school children. Social Indicators Research, $110(3)$, 913-924. https://doi.org/10.1007/s11205-0119964-9

Tu, Y., \& Zhang, S. (2014). Loneliness and subjective well-being among chinese undergraduates: The mediating role of self-efficacy. Social Indicators Research, 124(3), 963-980. https://doi.org/10.1007/s11205-0140809-1

Utami, M. S. (2015). Keterlibatan dalam kegiatan dan kesejahteraan subjektif mahasiswa. Jurnal Psikologi, 36(2), 144163. https://doi.org/10.22146/jpsi.7892

Peraturan Rektor Undip Nomor 4. (2014). Organisasi Kemahasiswaan. Universitas Diponegoro. Semarang. https://htl.undip.ac.id/v1/peraturanrektor/

Vanhoutte, B., \& Nazroo, J. (2014). Cognitive, affective and eudemonic wellbeing in later life: measurement equivalence over gender and life stage. Sociological Research Online, 19(2), 114. https://doi.org/10.5153/sro.3241

Zhang, D. C., \& Renshaw, T. L. (2020). Personality and college student subjective wellbeing: A domain-specific approach. Journal of Happiness Studies, 21(3), 9971014. https://doi.org/10.1007/s10902019-00116-8 